\title{
Molecular Appraisement of Isolated Antibiotic Resistant Enterococci from Vaginal Specimen in Spontaneously Abortion Women's
}

\author{
Seyedeh Marzieh Moosavi ${ }^{1}$, Abbas Akhavan Sepahi ${ }^{1}$, Vajihe Sadat Nikbin ${ }^{2}$, Seyed Fazlollah \\ Mousavi $^{2 *}$, Maryam Agha Abassi ${ }^{2}$ and Bahman Mirzaei ${ }^{2,3}$ \\ ${ }^{1}$ Department of Microbiology, Faculty of biology, Islamic Azad University, North Branch, Tehran, Iran. \\ ${ }^{2}$ Department of Microbiology, Pasteur Institute of Iran, Tehran. Pasteur Institute of Iran. \\ ${ }^{3}$ Department of Microbiology, Medical Science Faculty, Mazandaran University of Medical Science.
}

Received: 26 January, 2017; Accepted: 28 February, 2017; Published: 6 February, 2017

*Corresponding author: Seyed Fazlollah Mousavi, Department of Microbiology, Pasteur Institute of Iran, Tehran. Tel: +98(21) 66405535; Fax: +98(21) 66405535; Email: Mousavi@pasteur.ac.ir

\begin{abstract}
Enterococcus spp. as an opportunistic inhabitants of the gastrointestinal tract due to their potential antimicrobial resistance, are described as healthcare concern. Determination of virulence factors and genomic pattern of the isolated antibiotic resistant enterococci were the main goals of current research. Following the isolation of enterococcus spp. from 198 vaginal swab which were taken from women with spontaneous abortions, susceptibility of the isolates was assessed taking advantage of disk diffusion and Minimum Inhibitory Concentrations (MIC) methods. Subsequently, using the molecular approaches such as Pulse Field Gel Electrophoresis (PFGE) and Polymerase Chain Reaction (PCR) genetic relationship and presence of virulence genes (efaAfs, esp, asa1) among the isolates were screened. Out of one hundred ninety eight vaginal swab, 126 $(63.63 \%)$ strains were isolated as enterococci (Enterococcus faecalis $65 \%$, Enterococcus faecium 34\%). Oxacillin and imipenem were determined as highest and lowest resistance rates by disk diffusion. Following the MIC procedure, three antibiotics including Gentamicin (GM), Ciprofloxacin (CIP) and Vancomycin (VA) showed that the $5.5 \%, 15 \%$ and $0.8 \%$ of strains had high-level resistance, respectively. Prevalence of virulence genes in isolates were as follow, efaAfs (72.2\%), esp (36.5\%) and asa1 (64.2\%). From 59 strains of E. faecalis and E. faecium with resistance to antibiotics or containing virulence genes, 29 and 19 puls type were obtained by PFGE based on similarity of $90 \%$, respectively. In conclusion: Genomic patterns of resistant strains showed clonal relationship between the strains, while no clear correlation were obtained between clonality and virulence genes in studied isolates. Fortunately, no dominant pattern was identified in both dendrograms interpretation.
\end{abstract}

Keywords: Enterococcus spp., spontaneously abortion, virulence factors, Genomic patterns

\section{Introduction}

Enterococcus spp. are natural inhabitants of the gastrointestinal tract and the vagina in humans but has become increasingly important as hospital-acquired pathogens. They were established as a cause of urinary tract infections, endocarditis, post-surgical wounds, meningitis as well as septicemia [1-3]. Their naturally occurring or intrinsic resistance to various clinically antibiotic drugs, including penicillin and lowlevel resistance to amino glycoside appears to be due to their extraordinary capability to adapt themselves to antibiotics. They also evolved increased resistance by acquisition of antibiotic resistance to amino glycosides, glycopeptides and vancomycin [1,4-9]. Severe unfavorable outcomes such as prolonged periods of hospital stay, costly medical expenses and increase in mortality as a consequence of limited number of choices for existing antibiotics to cure the infection are the common possible complications caused by Vancomycin Resistant Enterococci (VRE) $[2,10]$. Enterococcal aggregation substances (agg), gelatinase (gelE), surface protein (esp), cell wall adhesions efaAfm and efaAfs of E. faecium and E. faecalis, respectively and cytolysin (cyl) are the virulence properties detected in enterococci and have been documented in several studies [8,11-16]. The existence of these virulence traits, intrinsic as well as acquired resistance and their role in human's infection are the possible criteria which can make these isolates as potential pathogens [17-20].

Aggregation substance encoded by asa1, as a pheromoneresponsive, for self-transferable plasmids, enterococcal surface protein encoded by chromosomal esp, which provide the possibility of immune system evasion in case of immune deficiency and the role of enterococcal surface protein in colonization and prolonged remain in the urinary tract, biofilm development and high virulence have been proved [21-24]. During puberty due to the presence of aerobic and anaerobic acid producing Lactobacillus, vagina's $\mathrm{pH}$ tends towards a more acidic $\mathrm{pH}$ which this provides an effective natural protection for the vagina against pathogens. If disruption of normal vaginal flora occurs, fungus and other microorganisms proliferate and lead to local manifestation of inflammations. Normal vaginal flora includes alpha-hemolytic streptococcus, anaerobic streptococcus (pepto streptococci), prevotella, clostridium, Gardnerella vaginalis, Ureaplasma urealyticum and sometimes listeria or mobiluncus 
species as well as lactobacillus. In some women vaginal opening possesses lots of bacteria similar to those which present in preneum and area around the anus. Presence of these kinds of bacteria provides the possibility of frequent urinary tract infections. Some bacteria such as Eshershia coli and enterococcus which reside in vagina and also proliferate there, because of proximity with anus have gastro vascular and fecal origins $[4,25]$.

The aim of this study was to study prevalence of enterococcus species in vaginal swabs and investigation of clonal relationship of the isolates regards to antibiotic resistance patterns and virulence genes.

\section{Material and Methods}

\section{Strain isolation and identification}

A total of 198 vaginal swabs were taken from women with spontaneous abortions in Khorramabad city, Iran, from January 2014 to December 2015. Isolated strains were identified using the conventional microbial tests according to the scheme utilized as previously described [26,27]. All isolates were stored at freezer in Brain Heart Infusion Broth (BHI) with 18\% Glycerol. Isolation rate of bacterial contamination in target group was compared by collected vaginal swaps from women without abortion too.

\section{Antibiotic susceptibility testing}

Susceptibility testing for Enterococci isolates was performed by disk diffusion and micro dilution broth according to the clinical laboratory standard institute guideline [8]. Disk diffusion method by utilizing disks (BD BBLTM Sensi DiscTM) containing erythromycin $(15 \mu \mathrm{g})$, chloramphenicol $(30 \mu \mathrm{g})$, ciprofloxacin $(5 \mu \mathrm{g})$, gentamicin $(10 \mu \mathrm{g})$, vancomycin $(30 \mu \mathrm{g})$, teicoplanin $(30 \mu \mathrm{g})$, oxacillin $(10 \mu \mathrm{g})$, imipenem $(10 \mu \mathrm{g})$ were applied. Results were obtained after incubation at $35^{\circ} \mathrm{C}$ for $24 \mathrm{~h}$ followed by inoculation of $1.5 \times 108 \mathrm{Cfu} / \mathrm{mL}$ (optical density 0.08-0.13 in $650 \mathrm{~nm}$ ) of tested isolates on Muller hint on Agar. The Minimum Inhibitory Concentration (MIC) of gentamicin, vancomycin and ciprofloxacin were also determined by the broth micro-dilution method [8]. E. faecalis strain ATCC 29212 was used as a quality control strain.

\section{DNA extraction}

Crud DNA was purified according to the previously published $[5,27]$

Briefly, growth colony harvested by centrifuge $8000 \mathrm{rpm}$ for 5 minutes. The pellets consisting of bacterial cells were used for DNA extraction process. Following three times boil and freezing procedure, total DNA was purified by high pure DNA extraction kits (Roche, Mannheim, Germany). Dried DNA was dissolved in $50 \mu \mathrm{l}$ of distilled water. Consequently, quantity of DNA was measured by Nanodrope (Spectrophotometer 1000) and adjusted to $300 \mathrm{ng} / \mu \mathrm{L}$.

\section{PCR for detection of esp, efaAfs and asa1genes}

Prevalence of targeted genes for isolates was screened by separate Polymerase Chain Reaction (PCR) as described previously $[28,29]$. Sequence of utilized primers in this study have been noticed in Table 1. PCR amplifications for esp and efaAfs genes were performed in final volume of a $25 \mu \mathrm{l} \mathrm{PCR}$ mixture, containing $12 \mu \mathrm{l}$ supernatant, $1 \mathrm{x}$ PCR buffer, $1.5 \mathrm{mM}$ $\mathrm{MgCl} 2,0.2 \mathrm{mM}$ each of dNTPs, 0.5 U Taq DNA polymerase (HT Biotechnology, Cambridge, UK) and each primer ( 5 pmol). PCR reaction consisted of denaturation $\left(94^{\circ} \mathrm{C}\right.$ for $\left.2 \mathrm{~min}\right)$, annealing $\left(55^{\circ} \mathrm{C}\right.$ for $\left.2 \mathrm{~min}\right)$, and elongation $\left(72^{\circ} \mathrm{C}\right.$ for $2 \mathrm{~min}$ ) followed by 29 cycles of denaturation $\left(92^{\circ} \mathrm{C}\right.$ for $\left.15 \mathrm{~s}\right)$, annealing $\left(55^{\circ} \mathrm{C}\right.$ for $\left.15 \mathrm{~s}\right)$ and elongation $\left(72^{\circ} \mathrm{C}\right.$ for $\left.15 \mathrm{~s}\right)$ and a final elongation of $72^{\circ} \mathrm{C}$ for 10 min. The asa1 gene was generated by same condition exception annealing 580C for $1 \mathrm{~min}$. Amplified products were analyzed by electrophoresis in a $1 \%$ agarose gel containing ethidium bromide with $100 \mathrm{bp}$ DNA ladder and visualiazed on a UV trans illuminator (Figure 1). E. faecalis ATCC 29212 containing esp and efaAfs genes and E. faecalis MMH 594 strains for asa1 gene were used as positive control.

\section{Pulsed-Field Gel Electrophoresis (PFGE)}

Totally 59 antibiotic resistant enterococcus strains possessing virulent genes have been studied by means of PFGE, of which 39 strains and 20 strains have been associated to $E$. faecalis and E. faecium respectively (Table 2). PFGE was carried out on a $1.0 \%$ agarose gel by using a CHEF-DR III apparatus (Bio-Red Laboratories, Richmond, CA, USA) in 0.5x TBE (Trisborate- EDTA) buffer at $14^{\circ} \mathrm{C}$ and $6 \mathrm{~V} / \mathrm{cm}$ as described previously [30]. After digestion with SmaI, genomic DNA was separated by electrophoresis (Figure 2,3). The gel were stained with ethidium bromide, distained, and photographed under ultraviolet. The banding patterns were interpreted by Dice analysis and clustered by the Unweighted Pair Group Method with arithmetic averages with Gel Compare II version 2.0 (Applied Maths, Sint-MatensLatem, Belgium).

Statistical analysis was accomplished taking advantage of Graph pad online software (Unpaired t test) and $p<0.05$ considered as significant.

\section{Results}

We have detected 126 enterococci isolates of totally 198 vaginal swabs, (81 E. faecalis (64.2\%) and 45 E. faecium $(35.7 \%)$ ).

\section{Antibacterial resistance}

The distribution of antibacterial resistance was obtained according to Table 3,4.

\begin{tabular}{|c|c|c|}
\hline \multicolumn{2}{|c|}{ Table 1: PCR primers and products for detection virulence determinants } \\
\hline $\begin{array}{c}\text { Gene and } \\
\text { primer }\end{array}$ & Sequence (5' to 3') & Products size (bp) \\
\hline $\begin{array}{c}\text { esp } \\
\text { TE34 }\end{array}$ & TTGCTAATGCTAGTCCACGACC & \\
TE36 & GCGTCAACACTTGCATTGCCGAA & \\
\hline efaAfs & & \\
TE5 & GACAGACCCTCACGAATA & \\
TE6 & AGTTCATCATGCTGTAGTA & 705 \\
\hline asa1 & & \\
F & CCAGCCAACTATGGCGGAATC & \\
R & CCTGTCGCAAGATCGACTGTA & 529 \\
\hline
\end{tabular}



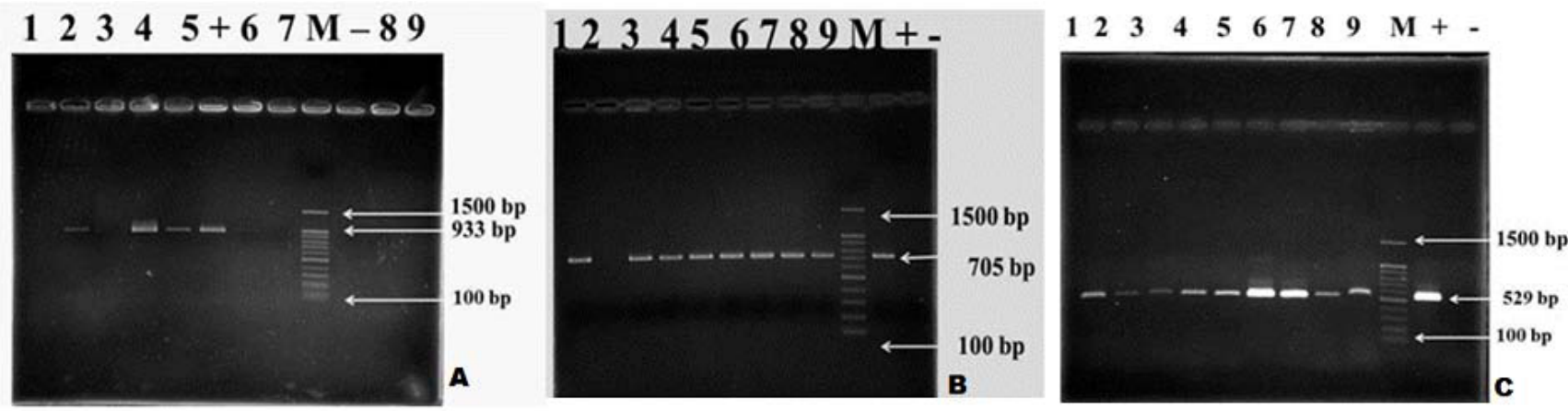

Figure 1: Determination of virulence genes esp, efaAfs and asa1 by PCR

A: PCR of esp gene- fragment size $933 \mathrm{bp}$, Columns 2, 4, 5, strains of enterococci that were positive for the gene, Column + and - : E. faecalis MMH 594 strain positive control and a negative control (water), Column M: Marker $100 \mathrm{bp}$.

B: PCR of efaAfs gene- fragment size $705 \mathrm{bp}$, Columns 1,3-9, strains of enterococci that were positive for the gene, Column + and - : E. faecalis ATCC 29212 positive control and a negative control (water), Column M: Marker $100 \mathrm{bp}$.

C: PCR of asa1 gene- fragment size 529 bp, Columns 1-9, strains of enterococci that were positive for the gene, Column + and - : E. faecalis MMH 594 positive control and a negative control (water), Column M: Marker $100 \mathrm{bp}$.

Table 2: PFGE- runnig parameters (set the voltage (200 V or $6 \mathrm{~V} / \mathrm{cm})$ )

\begin{tabular}{|c|c|c|}
\hline & $\begin{array}{c}\text { E. faecalis (1\% agarose } \\
\text { gel) }\end{array}$ & $\begin{array}{c}\text { E. faecium (1\% agarose } \\
\text { gel) }\end{array}$ \\
\hline${ }^{\mathbf{1}}$ Mode: & 1 & 1 \\
\hline Initial time: & $1 \mathrm{sec}$ & $1 \mathrm{sec}$ \\
\hline Final time: & $10 \mathrm{sec}$ & $13 \mathrm{sec}$ \\
\hline Start ratio: & 1 & 1 \\
\hline $\begin{array}{c}\text { Running } \\
\text { time: }\end{array}$ & $15 \mathrm{~h}$ & $13 \mathrm{~h}$ \\
\hline${ }^{2}$ Mode: & 10 & 10 \\
\hline Initial time: & $10 \mathrm{sec}$ & $13 \mathrm{sec}$ \\
\hline Final time: & $40 \mathrm{sec}$ & $30 \mathrm{sec}$ \\
\hline Start ratio: & 1 & 1 \\
\hline Running time & $10 \mathrm{~h}$ & $5 \mathrm{~h}$ \\
\hline${ }^{3}$ Mode: & 11 & 11 \\
\hline
\end{tabular}

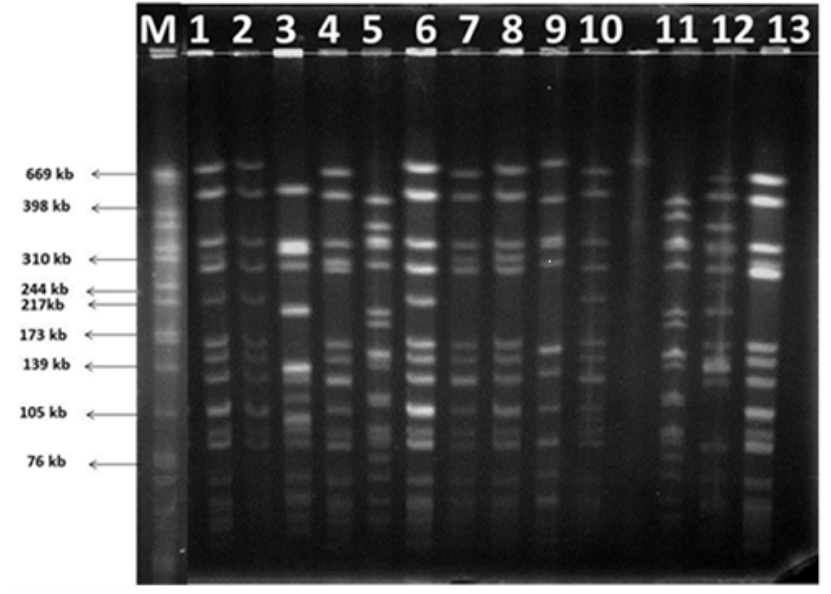

Figure 2: Results of PFGE of some Enterococcus isolates of this study, Column M, marker Salmonella cholerases.
Data demonstrated that imipenem is drug of choice for eradication of emerged infections caused by this genus respectively. According to the findings, for oxacillin susceptibility testing ( $99 \%$ resistance) our commentary was that, all of isolates have beta lactamase enzyme. This phenomena must be analyzed by confirmatory method such as PCR in future studies.

Detailed data for each antibiotic pattern was indicated at the Table 3.

According to CLSI (2011), High- level resistance to gentamicin (MIC $\geq 500 \mu \mathrm{g} / \mathrm{ml}$ ), ciprofloxacin (MIC $\geq 32 \mu \mathrm{g} / \mathrm{ml}$ ) and vancomycin (MIC $\geq 64 \mu \mathrm{g} / \mathrm{ml}$ ) was detected in $5.5 \%, 3.17 \%$ and $0.8 \%$ of the isolates, respectively. In addition, $19(15 \%)$ of the isolates were resistant to ciprofloxacin (MIC $\geq 4 \mu \mathrm{g} / \mathrm{ml}$ ).

\section{Detection of virulence genes (esp, efaAfs, asa1)}

Determination of virulence genes esp, efaAfs and asa1 was based on size of PCR product (Figure 1). The genes esp, efaAfs and asa1 genes were observed among $36.5 \%, 72.2 \%$ and $64.2 \%$ of the isolates, respectively (Figure 3 ).

It was found that 46 of 126 enterococcus strains (36.5\%) were positive for the esp gene that contained 32 E. faecalis $(25.3 \%)$ and 14 E. faecium strains (11.1\%).

Our study also showed that only 91 strains $(72.2 \%)$ containing a set of 64 E. faecalis $(50.7 \%)$ and 27 E. faecium (21.4\%) strains were documented for the presence of efaAfs gene.

In addition, asa1 gene was found in 81 strains (64.2\%) among them $55(43.6 \%)$ and $26(20.6 \%)$ strains have been associated to E. faecalis and E. faecium, respectively (Details have been listed in Figure 3).

\section{The results of PFGE}

The results obtained from separate gels were analyzed and compared with the size marker Salmonella cholerasesuis serotype Braenderup using Gel compar II software (Figure 2). 


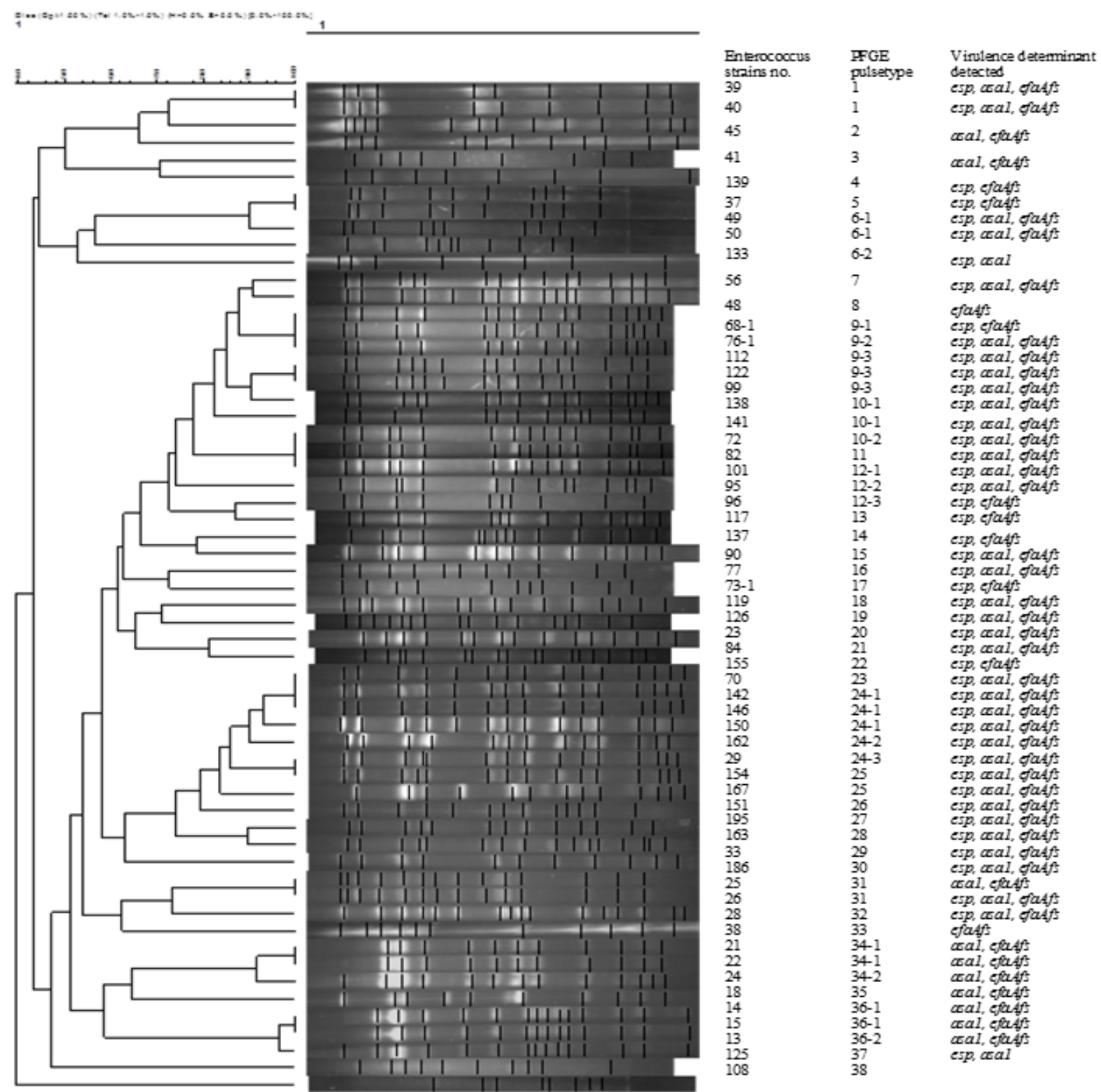

Figure 3: Detailed results of pulsed- field gel electrophoresis among Enterococcus species by Gel compare software and PFGE pulse type, detected virulence determinants.

Based on $90 \%$ genomic pattern similarity, genetic relationship between these E. faecalis and E. faecium were illustrated on two different dendrogram by Gel Compar II software (Figure 3). This genetic relationship among E. faecalis $(\mathrm{n}=39)$ and E. faecium $(\mathrm{n}$ $=20$ ) revealed 29 and 19 pulse-type with a low level of homology between strains in both species. Fortunately, no dominant pattern was identified in both dendrograms interpretation.

All in all, in dendrogram of E. faecalis 7 pulse-type included more than one strain identified while in dendrogram of E. faecium only one pulse-type included two strains with similar pattern.

\section{Discussion}

Enterococci spp., as one of the main inhabitants in intestinal and vaginal tract are considered as opportunistic bacteria for nosocomial infections [5,26]. In this study, 126 of the 198 vaginal swabs from women with frequent abortion were identified as enterococcus genus. This high incidence of enterococcus in vaginal swab is unusual, because the isolation of enterococcus from this area is less than $20 \%$ while in this study $65 \%$ of isolation was enterococcus $[1,11,25]$. In previous studies in Iran, 
Table 3: Detailed antibiotic suseptiblity pattern of isolated strains

\begin{tabular}{|c|c|c|c|c|c|c|c|c|c|c|c|}
\hline \multicolumn{3}{|c|}{ MIC } & \multicolumn{9}{|c|}{ Disk Diffusion } \\
\hline GM & CIP & VA & $\mathbf{O X}$ & VA & TEC & GM & $\mathbf{E}$ & CIP & C & CTX & IPM \\
\hline HLGR & $\mathrm{S}$ & $S$ & $\mathrm{R}$ & $\mathrm{S}$ & I & $S$ & $\mathrm{R}$ & $\mathrm{R}$ & $\mathrm{R}$ & $S$ & $\mathrm{~S}$ \\
\hline HLGR & $S$ & $S$ & $\mathrm{R}$ & $S$ & I & $S$ & $\mathrm{R}$ & $S$ & $S$ & I & $S$ \\
\hline $\mathrm{S}$ & HLR & $\mathrm{S}$ & $\mathrm{R}$ & $\mathrm{S}$ & I & $\mathrm{S}$ & I & I & $\mathrm{S}$ & I & $\mathrm{S}$ \\
\hline $\mathrm{S}$ & $\mathrm{S}$ & $\mathrm{S}$ & $\mathrm{R}$ & $\mathrm{S}$ & I & S & S & I & $\mathrm{S}$ & $\mathrm{R}$ & $\mathrm{S}$ \\
\hline $\mathrm{S}$ & $\mathrm{S}$ & $\mathrm{S}$ & $\mathrm{R}$ & $\mathrm{S}$ & I & $\mathrm{R}$ & $\mathrm{R}$ & $\mathrm{S}$ & $\mathrm{S}$ & I & $\mathrm{S}$ \\
\hline HLGR & $\mathrm{R}$ & $\mathrm{S}$ & $\mathrm{R}$ & $\mathrm{S}$ & $\mathrm{S}$ & $\mathrm{R}$ & $\mathrm{R}$ & I & $\mathrm{S}$ & $\mathrm{S}$ & $\mathrm{S}$ \\
\hline HLGR & $\mathrm{S}$ & $\mathrm{S}$ & $\mathrm{R}$ & $\mathrm{S}$ & I & $\mathrm{R}$ & $\mathrm{R}$ & I & $\mathrm{S}$ & $\mathrm{S}$ & $\mathrm{S}$ \\
\hline HLGR & $\mathrm{S}$ & $\mathrm{S}$ & $\mathrm{R}$ & $\mathrm{S}$ & I & $\mathrm{R}$ & $\mathrm{R}$ & $\mathrm{S}$ & $\mathrm{R}$ & $\mathrm{S}$ & $\mathrm{S}$ \\
\hline $\mathrm{S}$ & $\mathrm{R}$ & $\mathrm{S}$ & $\mathrm{R}$ & $\mathrm{S}$ & I & $\mathrm{R}$ & $\mathrm{R}$ & I & $\mathrm{S}$ & I & $\mathrm{S}$ \\
\hline $\mathrm{S}$ & $\mathrm{S}$ & $\mathrm{S}$ & $\mathrm{R}$ & $\mathrm{S}$ & $\mathrm{R}$ & $\mathrm{R}$ & $\mathrm{R}$ & I & $\mathrm{S}$ & $\mathrm{R}$ & $\mathrm{S}$ \\
\hline $\mathrm{S}$ & $\mathrm{R}$ & $\mathrm{S}$ & $\mathrm{R}$ & $\mathrm{S}$ & I & $\mathrm{S}$ & $\mathrm{S}$ & I & $\mathrm{S}$ & $\mathrm{R}$ & $\mathrm{S}$ \\
\hline HLGR & $\mathrm{S}$ & $\mathrm{S}$ & $\mathrm{R}$ & I & $\mathrm{R}$ & $\mathrm{R}$ & $\mathrm{R}$ & I & $\mathrm{R}$ & $\mathrm{R}$ & $\mathrm{S}$ \\
\hline $\mathrm{S}$ & $\mathrm{S}$ & $\mathrm{S}$ & $\mathrm{R}$ & $\mathrm{S}$ & I & $\mathrm{R}$ & $\mathrm{R}$ & $\mathrm{S}$ & $\mathrm{S}$ & $\mathrm{S}$ & $\mathrm{S}$ \\
\hline $\mathrm{S}$ & $\mathrm{S}$ & $\mathrm{S}$ & $\mathrm{R}$ & $\mathrm{S}$ & I & $\mathrm{S}$ & $\mathrm{R}$ & $\mathrm{R}$ & $\mathrm{R}$ & $\mathrm{S}$ & $\mathrm{S}$ \\
\hline $\mathrm{S}$ & $\mathrm{S}$ & $\mathrm{S}$ & $\mathrm{R}$ & $\mathrm{S}$ & I & $\mathrm{S}$ & $\mathrm{R}$ & $\mathrm{S}$ & S & I & $\mathrm{S}$ \\
\hline $\mathrm{S}$ & $\mathrm{S}$ & $\mathrm{S}$ & $\mathrm{R}$ & $\mathrm{S}$ & I & $\mathrm{S}$ & I & I & $\mathrm{S}$ & I & $\mathrm{S}$ \\
\hline $\mathrm{S}$ & $\mathrm{S}$ & $\mathrm{S}$ & $\mathrm{R}$ & $\mathrm{S}$ & I & $\mathrm{R}$ & $\mathrm{R}$ & $\mathrm{S}$ & $\mathrm{S}$ & I & $\mathrm{S}$ \\
\hline $\mathrm{S}$ & $\mathrm{S}$ & $\mathrm{S}$ & $\mathrm{R}$ & I & $\mathrm{R}$ & $\mathrm{R}$ & $\mathrm{R}$ & I & $\mathrm{S}$ & I & $\mathrm{S}$ \\
\hline $\mathrm{S}$ & $\mathrm{S}$ & $\mathrm{S}$ & $\mathrm{R}$ & $\mathrm{S}$ & $\mathrm{S}$ & $S$ & $\mathrm{R}$ & $\mathrm{S}$ & $\mathrm{R}$ & $\mathrm{S}$ & $\mathrm{S}$ \\
\hline $\mathrm{S}$ & $S$ & $\mathrm{~S}$ & $\mathrm{R}$ & $\mathrm{S}$ & I & $\mathrm{S}$ & $\mathrm{S}$ & $\mathrm{S}$ & & I & $\mathrm{S}$ \\
\hline $\mathrm{S}$ & $\mathrm{S}$ & $\mathrm{S}$ & $\mathrm{R}$ & $\mathrm{S}$ & I & $\mathrm{S}$ & $S$ & $\mathrm{~S}$ & & $\mathrm{~S}$ & $\mathrm{~S}$ \\
\hline $\mathrm{S}$ & $\mathrm{S}$ & $\mathrm{S}$ & $\mathrm{R}$ & $\mathrm{S}$ & $\mathrm{S}$ & $\mathrm{S}$ & $\mathrm{R}$ & $\mathrm{S}$ & & I & $\mathrm{S}$ \\
\hline $\mathrm{S}$ & $\mathrm{S}$ & $\mathrm{S}$ & $\mathrm{R}$ & $\mathrm{R}$ & $\mathrm{R}$ & S & $\mathrm{R}$ & $\mathrm{S}$ & & I & $\mathrm{S}$ \\
\hline $\mathrm{S}$ & $\mathrm{S}$ & $\mathrm{S}$ & $\mathrm{R}$ & $\mathrm{S}$ & $\mathrm{S}$ & $\mathrm{S}$ & $\mathrm{S}$ & I & & $\mathrm{S}$ & $\mathrm{S}$ \\
\hline $\mathrm{S}$ & $\mathrm{S}$ & $S$ & $\mathrm{R}$ & $\mathrm{S}$ & $\mathrm{R}$ & $\mathrm{R}$ & $\mathrm{R}$ & $\mathrm{S}$ & & I & $\mathrm{S}$ \\
\hline $\mathrm{S}$ & $\mathrm{S}$ & $\mathrm{S}$ & $\mathrm{R}$ & $\mathrm{S}$ & $\mathrm{S}$ & $\mathrm{S}$ & $\mathrm{R}$ & $\mathrm{S}$ & & $\mathrm{S}$ & $\mathrm{S}$ \\
\hline $\mathrm{S}$ & $\mathrm{S}$ & $\mathrm{S}$ & $\mathrm{R}$ & $\mathrm{S}$ & $\mathrm{R}$ & $\mathrm{R}$ & $\mathrm{R}$ & $\mathrm{S}$ & & $\mathrm{R}$ & $\mathrm{S}$ \\
\hline $\mathrm{S}$ & $\mathrm{S}$ & $\mathrm{S}$ & $\mathrm{R}$ & $\mathrm{S}$ & I & $\mathrm{S}$ & $\mathrm{R}$ & $\mathrm{S}$ & & $\mathrm{R}$ & $\mathrm{S}$ \\
\hline $\mathrm{S}$ & $\mathrm{S}$ & $\mathrm{S}$ & $\mathrm{R}$ & $\mathrm{S}$ & I & $\mathrm{S}$ & $\mathrm{R}$ & I & & $\mathrm{R}$ & $\mathrm{S}$ \\
\hline $\mathrm{S}$ & $\mathrm{S}$ & $\mathrm{S}$ & $\mathrm{R}$ & $\mathrm{S}$ & I & $\mathrm{S}$ & I & $\mathrm{S}$ & & I & $\mathrm{S}$ \\
\hline HLGR & $\mathrm{S}$ & S & $\mathrm{R}$ & $\mathrm{S}$ & I & $S$ & $\mathrm{R}$ & $\mathrm{S}$ & $\mathrm{S}$ & I & $\mathrm{S}$ \\
\hline $\mathrm{S}$ & $\mathrm{S}$ & S & $\mathrm{R}$ & I & I & I & I & $\mathrm{S}$ & $\mathrm{R}$ & $\mathrm{S}$ & \\
\hline $\mathrm{S}$ & $\mathrm{S}$ & $\mathrm{S}$ & I & I & $\mathrm{S}$ & $\mathrm{S}$ & $S$ & $\mathrm{~S}$ & S & $\mathrm{S}$ & \\
\hline $\mathrm{S}$ & $\mathrm{R}$ & $\mathrm{S}$ & $\mathrm{R}$ & $\mathrm{S}$ & I & I & $\mathrm{R}$ & I & $\mathrm{S}$ & $\mathrm{S}$ & \\
\hline $\mathrm{S}$ & $\mathrm{S}$ & $\mathrm{S}$ & $\mathrm{R}$ & I & I & I & $\mathrm{S}$ & $\mathrm{R}$ & $\mathrm{S}$ & $\mathrm{S}$ & \\
\hline $\mathrm{S}$ & $\mathrm{S}$ & $\mathrm{S}$ & $\mathrm{R}$ & $\mathrm{S}$ & I & $\mathrm{R}$ & $\mathrm{R}$ & $\mathrm{S}$ & $S$ & $\mathrm{~S}$ & \\
\hline $\mathrm{S}$ & $\mathrm{S}$ & $\mathrm{S}$ & $\mathrm{R}$ & $\mathrm{S}$ & I & $\mathrm{R}$ & $\mathrm{R}$ & I & S & $\mathrm{S}$ & \\
\hline $\mathrm{S}$ & $\mathrm{S}$ & $\mathrm{S}$ & $\mathrm{R}$ & $\mathrm{S}$ & I & $\mathrm{R}$ & $\mathrm{R}$ & $\mathrm{R}$ & I & $\mathrm{S}$ & \\
\hline $\mathrm{S}$ & $\mathrm{S}$ & S & $\mathrm{R}$ & $\mathrm{S}$ & $\mathrm{R}$ & $\mathrm{S}$ & $\mathrm{S}$ & $\mathrm{S}$ & I & $\mathrm{S}$ & \\
\hline
\end{tabular}




\begin{tabular}{|c|c|c|c|c|c|c|c|c|c|c|}
\hline S & $\mathrm{R}$ & $\mathrm{S}$ & $\mathrm{R}$ & $S$ & $\mathrm{R}$ & $\mathrm{R}$ & $\mathrm{R}$ & I & I & $\mathrm{S}$ \\
\hline S & $\mathrm{R}$ & $\mathrm{S}$ & $\mathrm{R}$ & I & I & I & $\mathrm{R}$ & I & $\mathrm{R}$ & $\mathrm{S}$ \\
\hline$S$ & $S$ & $S$ & $\mathrm{R}$ & $S$ & $\mathrm{R}$ & $\mathrm{R}$ & $\mathrm{R}$ & $\mathrm{S}$ & $\mathrm{R}$ & $S$ \\
\hline S & $S$ & $S$ & $\mathrm{R}$ & $S$ & I & $S$ & $\mathrm{R}$ & $S$ & $\mathrm{R}$ & $\mathrm{S}$ \\
\hline S & S & $\mathrm{S}$ & $\mathrm{R}$ & $\mathrm{S}$ & I & $\mathrm{R}$ & $\mathrm{R}$ & $\mathrm{S}$ & S & $\mathrm{S}$ \\
\hline S & S & $\mathrm{S}$ & $\mathrm{R}$ & $\mathrm{S}$ & I & $\mathrm{R}$ & S & $\mathrm{R}$ & $\mathrm{R}$ & $\mathrm{S}$ \\
\hline S & S & $\mathrm{S}$ & $\mathrm{R}$ & $\mathrm{S}$ & $\mathrm{S}$ & I & $\mathrm{R}$ & $S$ & $\mathrm{R}$ & $\mathrm{S}$ \\
\hline$S$ & $S$ & $S$ & $\mathrm{R}$ & $S$ & $S$ & $\mathrm{R}$ & $\mathrm{R}$ & $S$ & $S$ & $S$ \\
\hline$S$ & $\mathrm{R}$ & $\mathrm{S}$ & $\mathrm{R}$ & $\mathrm{S}$ & $\mathrm{R}$ & I & $\mathrm{R}$ & $\mathrm{S}$ & $\mathrm{R}$ & $\mathrm{S}$ \\
\hline S & $\mathrm{R}$ & $\mathrm{S}$ & $\mathrm{R}$ & I & $\mathrm{R}$ & I & $\mathrm{R}$ & $\mathrm{R}$ & $\mathrm{R}$ & $\mathrm{S}$ \\
\hline S & $\mathrm{R}$ & $\mathrm{R}$ & $\mathrm{R}$ & I & $\mathrm{R}$ & I & $\mathrm{S}$ & I & I & $\mathrm{S}$ \\
\hline HLGR & $S$ & $S$ & $\mathrm{R}$ & $\mathrm{S}$ & I & $\mathrm{R}$ & $\mathrm{R}$ & I & I & $\mathrm{S}$ \\
\hline S & HLR & $\mathrm{S}$ & $\mathrm{R}$ & $S$ & S & $\mathrm{R}$ & $\mathrm{R}$ & $\mathrm{R}$ & $S$ & $\mathrm{~S}$ \\
\hline$S$ & HLR & $\mathrm{S}$ & $\mathrm{R}$ & $S$ & $S$ & I & $\mathrm{R}$ & $\mathrm{R}$ & $S$ & $\mathrm{~S}$ \\
\hline$S$ & HLR & $\mathrm{S}$ & $\mathrm{R}$ & $\mathrm{S}$ & $\mathrm{S}$ & I & $\mathrm{R}$ & $\mathrm{R}$ & $S$ & $\mathrm{~S}$ \\
\hline S & $S$ & $S$ & $\mathrm{R}$ & $S$ & I & $S$ & I & I & I & $\mathrm{S}$ \\
\hline S & $\mathrm{R}$ & $\mathrm{S}$ & $\mathrm{R}$ & $\mathrm{S}$ & I & $\mathrm{R}$ & $\mathrm{R}$ & I & I & $\mathrm{S}$ \\
\hline$S$ & HLR & $S$ & $\mathrm{R}$ & $\mathrm{S}$ & $\mathrm{S}$ & $\mathrm{R}$ & $\mathrm{R}$ & $\mathrm{R}$ & $S$ & $\mathrm{~S}$ \\
\hline S & HLR & $S$ & $\mathrm{R}$ & $S$ & S & I & $\mathrm{R}$ & $\mathrm{R}$ & $S$ & $\mathrm{~S}$ \\
\hline$S$ & HLR & $\mathrm{S}$ & $\mathrm{R}$ & $S$ & $S$ & I & $\mathrm{R}$ & $\mathrm{R}$ & $S$ & $\mathrm{~S}$ \\
\hline$S$ & $S$ & $S$ & $\mathrm{R}$ & $S$ & I & $S$ & I & I & I & $\mathrm{S}$ \\
\hline S & $\mathrm{R}$ & $S$ & $\mathrm{R}$ & $S$ & I & $\mathrm{R}$ & $\mathrm{R}$ & I & I & $\mathrm{S}$ \\
\hline$S$ & HLR & $\mathrm{S}$ & $\mathrm{R}$ & $\mathrm{S}$ & $\mathrm{S}$ & $\mathrm{R}$ & $\mathrm{R}$ & $\mathrm{R}$ & $\mathrm{S}$ & $\mathrm{S}$ \\
\hline$S$ & HLR & $\mathrm{S}$ & $\mathrm{R}$ & $\mathrm{S}$ & $\mathrm{S}$ & I & $\mathrm{R}$ & $\mathrm{R}$ & $S$ & $\mathrm{~S}$ \\
\hline$S$ & HLR & $S$ & $\mathrm{R}$ & $S$ & $S$ & I & $\mathrm{R}$ & $\mathrm{R}$ & $S$ & $\mathrm{~S}$ \\
\hline
\end{tabular}

MIC: Minimum Inhibitory Concentration, GM: Gentamycin, CIP: Ciprofloxacin, VA: Vancomycin, OX: Oxacillin, TEC: Teicoplanin, E: Erythromycin, C: Chloramphenicol, CTX: Cefotaxime/Clavulanic acid, IP: Imipenem, HLR: High Level Resistant, S: Susceptible, I: Intermediate, R: Resistant

Table 4: Antibiogram results of 126 strains of Enterococcus

\begin{tabular}{|c|c|c|c|}
\hline Antibiotics & Resistance & Intermediate & Sensitive \\
\hline Oxacillin & $100 \%$ & $0 \%$ & $0 \%$ \\
\hline $\begin{array}{c}\text { Cefotaxime/Clavulanic } \\
\text { acid }\end{array}$ & $36.5 \%$ & $31.7 \%$ & $31.7 \%$ \\
\hline Imipenem & $0 \%$ & $0 \%$ & $100 \%$ \\
\hline Gentamicin & $29.3 \%$ & $15.8 \%$ & $54.7 \%$ \\
\hline Vancomycin & $3.1 \%$ & $14.2 \%$ & $82.5 \%$ \\
\hline Teicoplanin & $18.2 \%$ & $69 \%$ & $12.6 \%$ \\
\hline Erythromycin & $63.4 \%$ & $17.4 \%$ & $19 \%$ \\
\hline Chloramphenicol & $15.8 \%$ & $1.5 \%$ & $82.5 \%$ \\
\hline Ciprofloxacin & $11.1 \%$ & $31.7 \%$ & $57.1 \%$ \\
\hline
\end{tabular}

Italy and United states in 2010, 2004 and 2005, respectively, it was found that prevalence of virulent genes among nosocomial isolates are higher than non-nosocomial ones including faeces of healthy people, swage, animal and environmental isolates. Thus, it could be found that these virulent genes have a main role in transmission of infection as well as its stability [25,28,31] According to the Creti findings the presence of genes asa 1 and asa373, cylA, esp, gelE, ace and efaA in invasive and non-invasive infections was different the presence genes were as follow; asa1 gene $(63.3 \%)$ and gel $(83.3 \%)$ in invasive infections and in non- invasive infection asa1 gene was dominant $(100 \%)$ in non-invasive infection respectively [25]. Our results confirmed the Creti obtained results and the frequency of asa1 in vaginal soaps with spontaneous abortion was $64 \%$ too. Virulence of the enterococci could be enhanced by expression of the esp gene due to association of esp with colonization an persistence in urinary tract and biofilm formation [25]. We determined that the prevalence of esp was significant $(P=0.001)$ in the vaginal of the women with abortion. Also asa1 Gene in E. faecalis and E. faecium strains were significant were compared by resulting of control group. A study which has been done in Thailand in 2011 revealed that the prevalence of esp virulent gene in 45 high level gentamicin resistant $E$.faecalis isolates was $86.6 \%$, while in other study esp gene has been detected in all three high level gentamicin resistant strains which potentially resulted in the diseases [31]. It seems that different virulence genes prevalence rates between the current and previous studies could be due 
to different origins of the isolates [22,25,28,31]. Complete or relative resistance to $\beta$-lactams is a characteristic feature of the genus Enterococcus an additional problem with enterococci is that they are typically tolerant to $\beta$-lactams (i.e., MBC/MIC of $>32$ ) [1]. The major mechanism underlying this resistance has been the production of low-affinity PBP [1]. Bactericidal combinations (e.g., ampicillin or penicillin G) for susceptible strains to penicillin and an aminoglycoside (e.g., gentamicin or streptomycin) to which the Enterococcus isolate does not exhibit high-level resistance are the best drug of choice for enterococcus infections [1]. Our finding demonstrate that, all isolates could be eradicated by imipenem. Vancomycin in combination with an amino glycoside has demonstrated synergistic activity against enterococci both in vitro and in vivo [1]. However, enterococci are becoming increasingly resistant to traditional antibiotic therapy. In addition to high-level amino glycoside resistance and ampicillin resistance, rapid spread of vancomycin resistance has resulted in limited therapeutic alternatives. Our isolated strains due to susceptibility patterns indicated that the probably $29 \%$ and $31 \%$ isolates were resistant against gentamycin and vancomycin respectively.

The PFGE has been performed to investigate the phylogenetic association of resistant strains carrying virulence genes. In this investigation, 7 out of 29 obtained pulse-types from E. faecalis consisted of more than one strain. In other words, these types two or several strains with identical pattern were identified (Figure 2, 3). Pulse-types number 17 and 27 included the highest number of strains (4 and 3, respectively). In the pulse-type number 17 , 3 out of 4 strains represented identical pattern and another strain was closely related and showed more than $90 \%$ similarity. In this pulse-type, similar antibiotic resistance pattern as well as similar genotype based on virulence genes (esp, asa1, efAfs) were identified with the exception of closely related strain which was different in resistance to erythromycin and teicoplanin. Moreover, in this dendrogram pulse-type number 28 consisted of two closely related strains with completely different resistance to gentamicin. It appears that one of the way of developing resistance against amino glycosides is to acquire resistance gene via conjugative transposons.

Resistance to CIP were observed among the strains both in the same or different pulse-types. Strain 154 has been isolated from a hospitalized patient and represented MIC $\geq 4 \mu \mathrm{g} / \mathrm{ml}$ to ciprofloxacin while its similar strain (167) has been isolated from an outpatient with no resistance to ciprofloxacin. This demonstrated that resistance to CIP is possibly acquired in the hospital. According to our results, ciprofloxacin resistant strains (MIC $\geq 4 \mu \mathrm{g} / \mathrm{ml}$ ) or high gentamicin resistant strains (MIC $\geq$ $512 \mu \mathrm{g} / \mathrm{ml}$ ) have been classified in different pulse-types in both dendrogram and this demonstrated resistance dissemination in various clones with different sources showing horizental transfer of resistance among different strains. Two distinct outpatients were observed in pulse-types 7 and 17 which may be indicative of strain's distribution in a non-hospital setting that requires further study in this field. According to dendrogram of 20 E. faecium isolates, only one pulse-type (number 1) included two identical strains with similar virulence genotype as well as identical antibiotic resistance patterns with the exceptation of $\mathrm{C}$ antibiotic was obtained. Other $E$.faecium strains were classified in one pulse-type distinctly. Strain 28 which is ordered in pulsetype number 10 represented high resistance to vancomycin and this provide evidence that the origin of this strain is totally different and fortunately it showed no clonal dissemination. Like the results of our study, more similarity amongst $E$. faecalis strains than E. faecium was observed previously [16]. Recent studies, provided the evidence that the strains could disseminate easily due to either lack of hygiene in hospital's staff or lack of appropriate isolation in patients possessing infection caused by resistant strains and this phenomenon could occur in different hospitals as well as society [30,32-35]. If the control of infection does not exert in hospitals, these resistant strains possessing virulent genes would be disseminated either from one individual to another one or from one hospital to another one via patients or staffs. Sometimes the disseminated clone has important characteristic such as virulent gene or high resistance, so that preventing of such strains from spread is very important. Studies on one prevalent epidemic clone in the burn unit of a hospital in Taiwan showed that this epidemic clone remained longer in patient's body than non-clonal strains and cause various and severe infections [36]. Since the strains with identical genotypes from aspect of virulent genes represented different types of PFGE or the strains with different genotype showed similar patterns, it could be identified that there is no association between virulent genotypes and PFGE patterns. The typing method for high level ciprofloxacin, gentamicin and vancomycin resistant enterococcus harboring possessing virulent genes represented differences between these isolates due to different isolates origin. Luckily, in the current study no prevalent clonal dissemination amongst strains has been observed but according to result's interpretation of two dendrogram corresponded to E. faecalis and E. faecium, 5 and 1 pulse-types possessed common strains was observed, respectively. Since the common strains could survive in hospitals, antibiotic resistance information such as anti biogram and minimum inhibitory concentration could help to control of infection effectively. Moreover, by proper hygiene measures clonal dissemination could best be prevented in the future.

\section{Conclusion}

Genomic patterns of resistant strains showed clonal relationship between the strains, while no clear correlation were obtained between clonality and virulence genes in studied isolates. Fortunately, no dominant pattern was identified in both dendrograms interpretation. Although incidence of enterococcus in healthy vaginal swab is unusual, but due to isolation rates of mentioned bacteria from spontaneous abortion women, this genus must be assigned as a probable cause of abortion too. Series of measures must be taken for rapid identification and prevention of bacterial colonization in healthy vaginal tract.

\section{Acknowledgments}

The authors wish to acknowledge the Pasteur Institute of Iran for funding through a Ph.D. studentship. The authors are grateful 
for the support of the dear colleagues in Bacteriology Department Pasteur Institute of Iran.

\section{Ethical statement}

This study was financially supported by Pasteur Institute of Iran, Tehran, Iran. (Funding number B9008).

\section{References}

1. Cetinkaya Y, Falk P, Mayhall CG. Vancomycin-resistant enterococci. Clin Microbiol Rev. 2000;13(4):686-707.

2. Huycke MM, Sahm DF, Gilmore MS. Multiple-drug resistant enterococci: The nature of the problem and an agenda for the future. Emerg Infect Dis. 1998;4(2):239-249.

3. Jones RN, Marshall SA, Pfaller MA, Wilke WW, Hollis RJ, Erwin ME, et al. Nosocomial enterococcal blood stream infections in the SCOPE program: antimicrobial resistance, species occurrence, molecular testing results and laboratory testing accuracy. SCOPE Hospital Study Group. Diagn Microbiol Infect Dis. 1997;29(2):95-102.

4. Donskey CJ, Schreiber JR, Jacobs MR, Shekar R, Salata RA, Gordon S, et al. A polyclonal outbreak of predominantly VanB vancomycin-resistant enterococci in North East Ohio. Northeast Ohio vancomycin-resistant Enterococcus surveillance program. Clin Infect Dis. 1999;29(3):573579.

5. Mirzaei B, Farivar TN, Juhari P, Mehr MA, Babaei R. Investigation of the Prevalence of vanA and vanB genes in vancomycin resistant enterococcus (VRE) by Taq Man real time PCR Assay. JMID. 2013;3(4):192-198.

6. Nelson RR, McGregor KF, Brown AR, Amyes SG, Young HK. Isolation and characterization of glycopeptide-resistant enterococci from hospitalized patients over a 30-month period. J Clin Microbiol. 2000;38(6):2112-2116.

7. Olmsted SB, Dunny GM, Erlandsen SL, Wells CL. A plasmid-encoded surface protein on Enterococcus faecalis augments its internalization by cultured intestinal epithelial cells. J Infect Dis. 1994;170(6):15491556.

8. Quale J, Landman D, Atwood E, Kreishwirth B, Willey BM, Ditore V, et al. Experience with a hospital-wide outbreak of vancomycin-resistant enterococci. Am J Infect Control. 1996;24(5):372-379.

9. Schouten MA, Hoogkamp-Korstanje JA, Meis JF, Voss A. Prevalence of vancomycin-resistant enterococci in Europe. Eur J Clin Microbiol Infect Dis. 2000;19(11):816-822.

10. Linden PK, Pasculle AW, Manez R, Kramer DJ, Fung JJ, Pinna AD, et al. Differences in outcomes for patients with bacteremia due to vancomycin-resistant Enterococcus faecium or vancomycin susceptible E. faecium. Clin Infect Dis. 1996;22(4):663-670.

11. Cariolato D, Andrighetto C, Lombardi A (2008) Occurrence of virulence factors and antibiotic resistances in Enterococcus faecalis and Enterococcus faecium collected from dairy and human samples in North Italy. Food Control, 19,886-892.
12. Eaton TJ, Gasson MJ. Molecular screening of Enterococcus virulence determinants and potential for genetic exchange between food and medical isolates. Appl Environ Microbiol. 2001;67(4):1628-1635.

13. Franz CM, Holzapfel WH, Stiles ME. Enterococci at the crossroads of food safety? Int J Food Microbiol. 1999;47(1-2):1-24.

14. Reinert RR, Conrads G, Schlaeger JJ, Werner G, Witte W, Lütticken R, Klare I. Survey of antibiotic resistance among enterococci in North Rhine-Westphalia, Germany. J Clin Microbiol. 1999;37(5):1638-1641.

15. Semedo T, Santos MA, Lopes MF, Marques JJ, Crespo MT, Tenreiro R. Virulence factors in food, clinical and reference enterococci: A common trait in the genus? Syst Appl Microbiol. 2003;26(1):13-22.

16. Valenzuela AS, Omar NB, Abriouel H, López RL, Ortega E, Cañamero $\mathrm{MM}$, et al. Risk factors in enterococci isolated from foods in Morocco: Determination of antimicrobial resistance and incidence of virulence traits. Food Chem Toxicol. 2008;46(8):2648-2652.

17. Franz CM, Muscholl-Silberhorn AB, Yousif NM, Vancanneyt M, Swings J, Holzapfel WH. Incidence of virulence factors and antibiotic resistance among enterococci isolated from food. Appl Environ Microbiol. 2001;67(9):4385-4389.

18. Giraffa G. Enterococci from foods. FEMS Microbiol Rev. 2002;26(2):163171.

19. Guzman CA, Pruzzo C, LiPira G, Calegari L. Role of adherence in pathogenesis of Enterococcus faecalis urinary tract infection and endocarditis. Infect Immun. 1989;57(6):1834-1838.

20. Lloyd S, Zervos M, Mahayni R, Lundstrom T. Risk factors for enterococcal urinary tract infection and colonization in a rehabilitation facility. Am J Infect Control. 1998;26(1):35-39.

21.Galli, D, Lottspeich, F, Wirth, R. Sequence analysis of Enterococcus faecalis aggregation substance encoded by the sex pheromone plasmid pAD1. Mol Microbiol. 1990;4(6):895-904.

22. Shankar V, Baghdayan AS, Huycke MM, Lindahl G, Gilmore MS Infection-derived Enterococcus faecalis strains are enriched in esp, a gene encoding a novel surface protein. Infect Immun. 1999;67(1):193200.

23. Seno Y, Kariyama R, Mitsuhata R, Monden K, Kumon H. Clinical implications of biofilm formation by Enterococcus faecalis in the urinary tract. Acta Med Okayama. 2005;59(3):79-87.

24.Toledo-Arana A, Valle J, Solano C, Arrizubieta MJ, Cucarella C, Lamata $\mathrm{M}$, et al. The enterococcal surface protein, Esp, is involved in Enterococcus faecalis biofilm formation. Appl Environ Microbiol. 2001;67(10):4538-4545.

25. Creti R, Imperi M, Bertuccini L, Fabretti F, Orefici G, Di Rosa R, et al. Survey for virulence determinants among Enterococcus faecalis isolated from different sources. J Med Microbiol. 2004;53(Pt 1):13-20.

26. Mannu L, Paba A, Daga E, Comunian R, Zanetti S, Duprè I, et al. Comparison of the incidence of virulence determinants and antibiotic resistance between Enterococcus faecium strains of dairy, animal and 
clinical origin. Int J Food Microbiol. 2003;88(2-3):291-304.

27. Mirzaei B, Babaei R, Asiabar AP, Bameri Z. Detection of both vanA \& vanB genes in vanA phenotypes of Enterococci by Taq Man RT-PCR. Braz J Microbiol. 2015;46(1):161-165.

28. Jahangiri S, Talebi M, Eslami G, Pourshafie MR. Prevalence of virulence factors and antibiotic resistance in vancomycin-resistant Enterococcus faecium isolated from sewage and clinical samples in Iran. Indian J Med Microbiol. 2010;28(4):337-341.

29.0ancea DP. Enterococcal surface protein (Esp) œ epidemiology and transfer between enterococcal strains (Doctoral dissertation).

30. Hsueh PR, Teng LJ, Yang PC, Chen YC, Ho SW, Luh KT. Persistence of a multidrug-resistant Pseudomonas aeruginosa clone in an intensive care burn unit. J Clin Microbiol. 1998;36(5):1347-1351.

31. Seubwai C, Tattawawart U, Engchanill C.Virulence Factors in High-level Gentamicin Resistant Enterococcus faecalis Isolates from Hospitalized Patients. Srinagarind Med J.2011;26(3):207-212.
32. Lee SC, Wu MS, Shih HJ, Huang SH, Chiou MJ, See LC, et al. Identification of vancomycin-resistant enterococci clones and inter-hospital spread during an outbreak in Taiwan. BMC Infect Dis. 2013;13:163.

33. Morris JG, Shay DK, Hebden JN, McCarter RJ, Perdue BE, Jarvis W, et al. Enterococci resistant to multiple antimicrobial agents, including vancomycin. Establishment endemicity in a university medical center. Ann Intern Med. 1995;123(4):250-259.

34. Nikbin VS, Abdi-Ali A, Feizabadi MM, Gharavi S. Pulsed field gel electrophoresis \& plasmid profile of Pseudomonas aeruginosa at two hospitals in Tehran. Iran. Indian J Med Res. 2007;126(2):146-151.

35. Smith TL, Iwen PC, Olson SB, Rupp ME. Environmental contamination with vancomycin-resistant enterococci in an outpatient setting. Infect Control Hosp Epidemiol. 1998;19(7):515-518.

36. Weng PL, Ramli R, Shamsudin MN, Cheah YK, Hamat RA. High genetic diversity of Enterococcus faecium and Enterococcus faecalis clinical isolates by pulsed-field gel electrophoresis and multilocus sequence typing from a hospital in Malaysia. Biomed Res Int. 2013;2013:938937. 